Article

\title{
Coordination Compounds Featuring Non-Toxic Chiral 1,4-Dicarboxylic Acids and Copper(II)
}

\author{
Marius Kremer ${ }^{1}\left(\mathbb{D}\right.$, Jan van Leusen ${ }^{1}$ and Ulli Englert ${ }^{1,2}, *(\mathbb{D}$ \\ 1 Institute of Inorganic Chemistry, RWTH Aachen University, 52074 Aachen, Germany; \\ marius.kremer@ac.rwth-aachen.de (M.K.); jan.vanleusen@ac.rwth-aachen.de (J.v.L.) \\ 2 Institute of Molecular Science, Shanxi University, Taiyuan 030006, China \\ * Correspondence: ullrich.englert@ac.rwth-aachen.de
}

Received: 7 May 2020; Accepted: 3 June 2020; Published: 6 June 2020

\begin{abstract}
Six new coordination compounds of copper cations and 1,4-dicarboxylic acids have been synthesized and structurally investigated. Aspartic acid $\left(\mathrm{H}_{2}\right.$ asp), enantiopure, racemic and meso tartaric acid $\left(\mathrm{H}_{2}\right.$ tart), di-para-toluyltartaric acid $\left(\mathrm{H}_{2} \mathrm{dptta}\right)$ and dibenzoyltartaric acid $\left(\mathrm{H}_{2} \mathrm{dbta}\right)$ represent environmentally benign water-soluble proligands which may be deprotonated for oxygen coordination. Chelating ligands such as tetramethylethylenediamine (TMEDA) and 2-aminomethylpyridine (AMPY) efficiently reduce the dimensionality of the target compounds, and additional aqua ligands complete the coordination environments. In this line of argument, the discrete mononuclear complexes $\left[\mathrm{Cu}(\mathrm{AMPY})(\mathrm{asp})\left(\mathrm{H}_{2} \mathrm{O}\right)\right]$ and $\left[\mathrm{Cu}(\mathrm{Hdbta})_{2}\left(\mathrm{H}_{2} \mathrm{O}\right)_{4}\right]$ were obtained; for the latter, only a preliminary structure model can be presented which, however, agrees with the powder diffraction pattern of the bulk. From enantiopure and racemic tartaric acid and TMEDA the closely related chain polymers $\left.\left[\mathrm{Cu}^{\mathrm{II}}\left(\mathrm{H}_{2} \mathrm{tart}\right)(\mathrm{TMEDA})\left(\mathrm{H}_{2} \mathrm{O}\right)_{2}\right)\right]_{n}$ were obtained; the racemic compound consists of individual homochiral strands of opposite chirality. The high steric demand of di-para-toluyltartaric acid leads to one-dimensional $\left[\mathrm{Cu}(\mathrm{dptta})(\mathrm{EtOH})\left(\mathrm{H}_{2} \mathrm{O}\right)_{2}\right]_{n}$ with coordinated ethanol (EtOH) in the distant Jahn-Teller site of the coordination sphere. $\mathrm{Cu}(\mathrm{II})$, meso-tartaric acid and TMEDA aggregate to a trinuclear coordination compound $\left[\mathrm{Cu}^{\mathrm{II}}{ }_{2} \mathrm{Cu}^{\mathrm{I}}\left(\mathrm{H}_{2} \text { tart)(Htart)(TMEDA) }\right)_{2}\right]$. Its peripheral cations show the expected Jahn-Teller geometry of $\mathrm{Cu}(\mathrm{II})$, but the unambiguous assignment of the oxidation state $+\mathrm{I}$ for central cation required susceptibility measurements: their results prove the presence of only two and only very weakly interacting divalent cations, separated by a diamagnetic center.
\end{abstract}

Keywords: coordination compounds; low toxicity; chirality; blocking ligands; magnetochemistry; single crystal diffraction

\section{Introduction}

Carboxylic acids represent classical ligands for Werner complexes: As early as 1953, Niekerk et al. investigated the crystal structures of $\mathrm{Ni}$ (II) [1], Zn(II) [2] and $\mathrm{Cu}(\mathrm{II})$ [3] acetate and established the monohapto, chelating and bridging coordination modes, respectively, for the carboxylato ligand in these solids. Carboxylic acids may also act as bridging building blocks in coordination polymers (CPs) [4]. Among the many potentially attractive properties of CPs, we have focused on their dynamic responses to external stimuli such as temperature [5-8] or moisture $[9,10]$ in previous publications. In order to be really useful beyond basic research, the constituents of such dynamic materials should show low toxicity. Many carboxylic acids are found in the GRAS list, i.e., among the substances generally recognized as safe, e.g., by the FDA [11]. Carboxylic acids often show good solubility in water, and the chiral pool provides inexpensive and efficient access to a relevant number of enantiopure compounds. Amino acids meet the latter requirement par excellence, and their 
coordination chemistry has been investigated extensively [12-38]. Dicarboxylic acids are even more prone to act as bridging components than their monofunctional congeners and have been frequently employed for the construction of coordination polymers [39,40] and metal-organic frameworks [41]. In this contribution, we introduce six new coordination compounds in which dicarboxylic acids act as terminal ligands or as linkers between divalent $\mathrm{Cu}$ cations, and we address the influence of chirality and the effect of blocking ligands on their crystal structures. Figure 1 provides a summary of the reactions and the structurally characterized products.

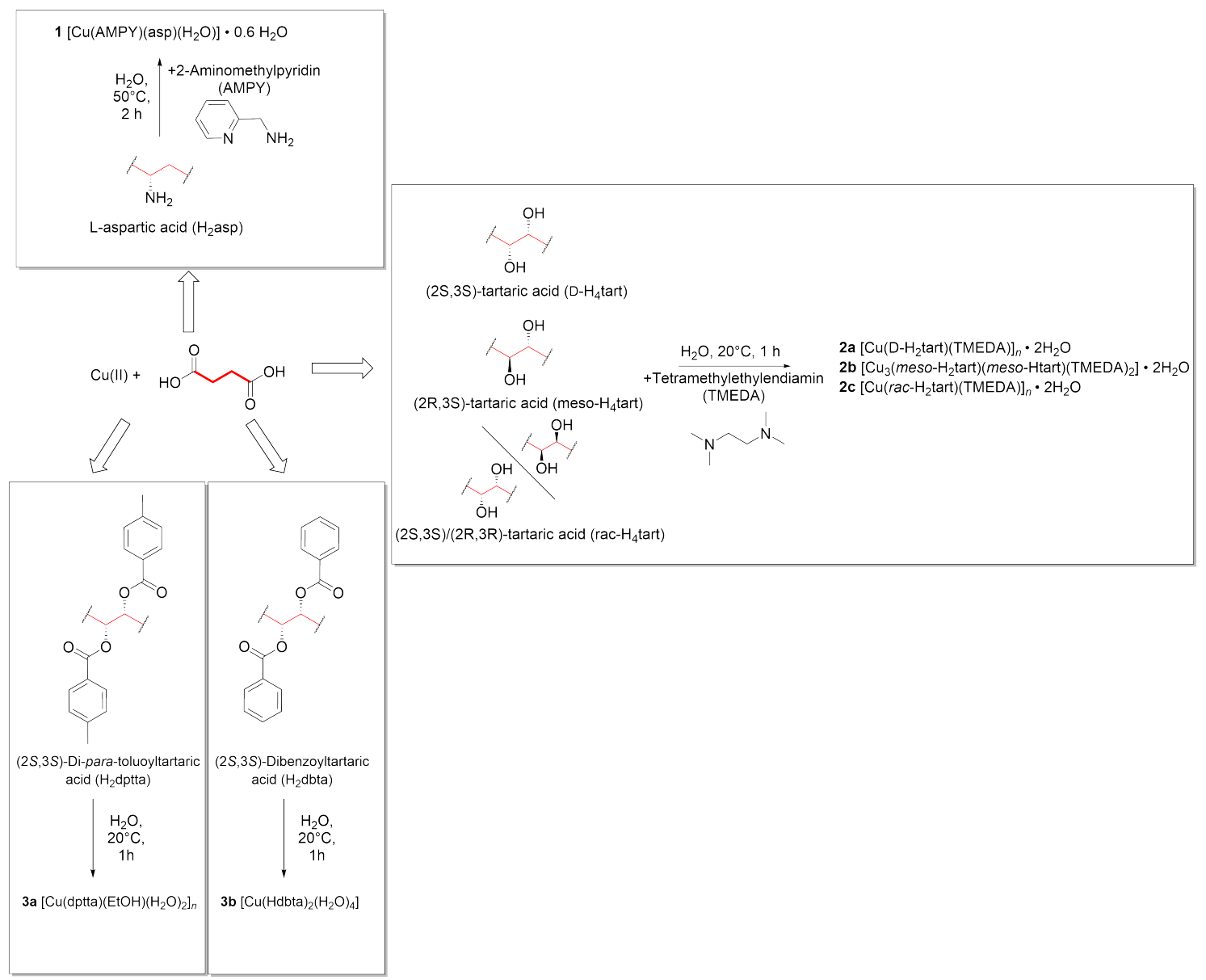

Figure 1. Schematic overview of the compounds synthesized and structurally characterized in this article.

\section{Results and Discussion}

In this section we will describe the new structures individually and put each of them into the scientific context of earlier work. Common features and underlying construction principles will be summarized in the Conclusions.

\subsection{Compound 1}

Building blocks in the crystal structure of $\mathbf{1}$ are discrete $\left[\mathrm{Cu}(\mathrm{AMPY})(\mathrm{asp})\left(\mathrm{H}_{2} \mathrm{O}\right)\right]$ complexes (AMPY = 2-aminomethylpyridine; asp = aspartate) and co-crystallized water molecules (Figure 2). The main complex molecule occupies a general position in the orthorhombic space group $P 2{ }_{1}{ }_{1} 2$ and features a strongly Jahn-Teller distorted pseudo-octahedron about the $\mathrm{Cu}(\mathrm{II})$ cation. 


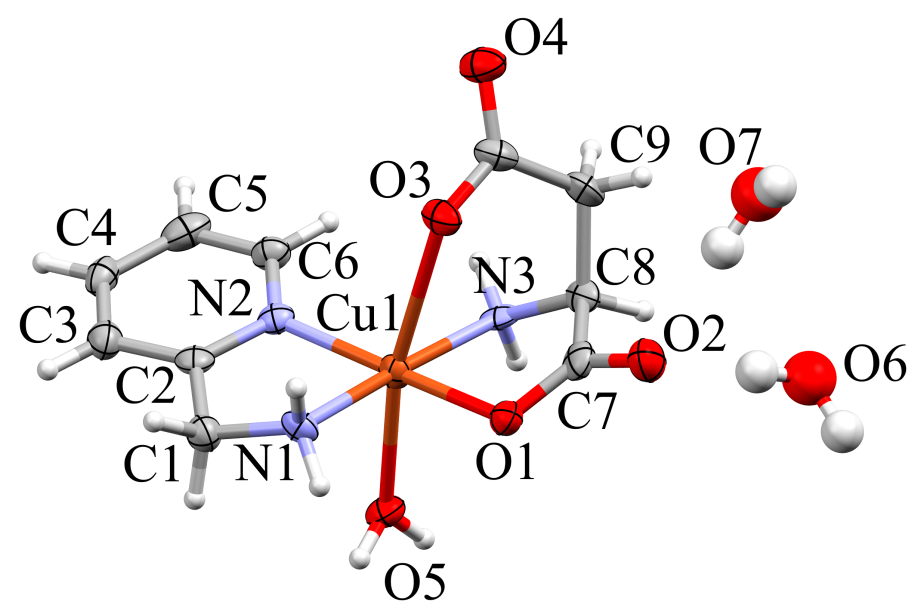

Figure 2. Expanded asymmetric unit of 1 (Mercury, [42]). Non-hydrogen atoms in the complex are shown as ellipsoids (70\% probability), $\mathrm{H}$ as spheres with fixed radius of $0.15 \AA$, atoms in co-crystallized water molecules as spheres with $0.25 \times$ the van der Waals radii. Coordination distances $(\AA): \mathrm{Cu} 1-\mathrm{N} 1$ = 1.989(5), Cu1-O1 = 1.991(4), Cu1-N2 = 1.992(5), Cu1-N3 = 2.010(5), Cu1-N5 = 2.374(5).

The $\mathrm{N}, \mathrm{N}^{\prime} \mathrm{AMPY}$ chelate, the carboxylato $\mathrm{O}$ atom $\mathrm{O} 1$ and the asp amino nitrogen act as equatorial ligands, the second asp carboxylato group and the aqua ligand associated with O5 occupy the more distant axial positions.

1 represents the first example in which a primary aliphatic amine acts as co-ligand for aspartate. Generally spoken, $\mathrm{O}, \mathrm{N}, \mathrm{O}^{\prime}$ tris-chelation by aspartate is not unprecedented for $\mathrm{Cu}(\mathrm{II})$ with additional $\mathrm{N}$ donor ligands. Notable examples include derivatives with 2,2'-bipyridine (IYEQAE [43]), the structures are deposited in the Cambridge Structural Database [44] under these six letter reference codes), 4,4'-bipyridine (OVAZUH [45], WIWJAO [46]), phenanthroline (DUCFEM [47], FAPJAI [48], WINGUV [49]), dipyridylethylene (WIWHUG [46]) or more complex imidazole ligands (OVAZOB [45]).

The co-crystallized water molecules are situated on twofold crystallographic axes (Wyckoff positions $2 a$ and $2 b$ ); refinement of their site occupancies resulted in a stoichiometry of $\left[\mathrm{Cu}(\mathrm{AMPY})(\operatorname{asp})\left(\mathrm{H}_{2} \mathrm{O}\right)\right] \cdot 0.6 \mathrm{H}_{2} \mathrm{O}$, in agreement with the microanalytical data. Additional details concerning the site occupancy are given in Supplementary Materials S1.3.1.

The crystal structure is stabilized by a maximum of classical hydrogen bonds which connect the constituents to a three-dimensional network: All hydrogen atoms bonded to $\mathrm{N}$ or $\mathrm{O}$ find an electronegative acceptor at a suitable distance. Table S8 summarizes all hydrogen bonds. In addition, neighboring molecules along $\left[\begin{array}{lll}0 & 1 & 0\end{array}\right]$ interact via $\pi$ stacking, with shortest $C \cdots C$ distances of $3.4 \AA$.

\subsection{Compound $\mathbf{2 a}$}

The crystal structure of $\mathbf{2 a}$ is made up of one-dimensional $\left[\mathrm{Cu}\left(\mathrm{D}-\mathrm{H}_{2} \operatorname{tart}\right)(\mathrm{TMEDA})\right]_{n}$ strands in [ $\left.\begin{array}{lll}1 & 0 & 0\end{array}\right]$ direction (TMEDA = tetramethylethylenediamine; $\mathrm{H}_{2} \mathrm{tart}=$ tartrate) and co-crystallized water molecules. The asymmetric unit of space group $P 2_{1}$ contains a single chain link and is depicted in Figure 3. Its $\mathrm{Cu}(\mathrm{II})$ center features an elongated Jahn-Teller octahedron. 


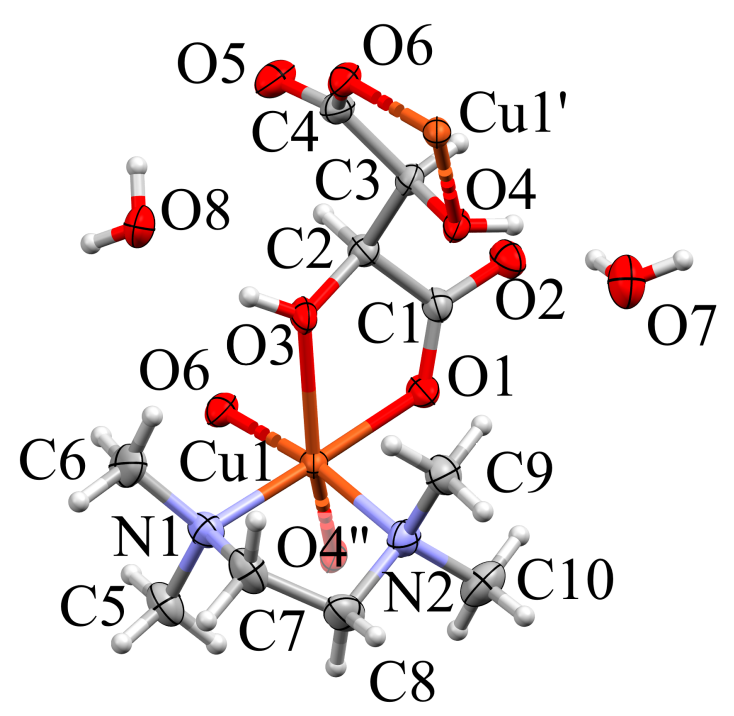

Figure 3. Expanded asymmetric unit of 2a (Mercury, [42]). Non-hydrogen atoms in the complex are shown as ellipsoids (70\% probability), $\mathrm{H}$ as spheres with fixed radius of $0.15 \AA$. Coordination distances $(\AA): \mathrm{Cu} 1-\mathrm{O} 1=1.967(4) \mathrm{Cu} 1-\mathrm{O} 6 "=1.990(4), \mathrm{Cu} 1-\mathrm{N} 1=2.052(5), \mathrm{Cu} 1-\mathrm{N} 2$ = 2.072(4), Cu1-O3 = 2.363(4), $\mathrm{Cu} 1-\mathrm{O} 4^{\prime \prime}=2.388(4)$. Symmetry codes: $\left(^{\prime}\right)=x-1, y, z ;\left(^{\prime \prime}\right)=x+1, y, z$.

The N,N $\mathrm{N}^{\prime}$ TMEDA chelate and the carboxylato $\mathrm{O}$ atoms $\mathrm{O} 1$ and $\mathrm{O6}^{\prime \prime}$ act as equatorial ligands, the two hydroxy $\mathrm{O}$ atoms $\mathrm{O} 3$ and $\mathrm{O} 4$ " occupy the more distant axial positions. The symmetry equivalent $\mathrm{O}^{\prime \prime}$ and $\mathrm{O}^{\prime \prime}$ are generated via translation along the chain direction (symmetry operator $x+1, y, z)$. With the co-crystallized water molecules, the stoichiometry of compound $2 \mathbf{a}$ is $\left[\mathrm{Cu}\left(\mathrm{D}-\mathrm{H}_{2} \text { tart)(TMEDA) }\right]_{n} \cdot 2 \mathrm{H}_{2} \mathrm{O}\right.$, in agreement with the microanalytical data. The co-crystallized water molecules connect adjacent $\left[\mathrm{Cu}\left(\mathrm{D}-\mathrm{H}_{2} \operatorname{tart}\right)(\mathrm{TMEDA})\right]_{n}$ strands via hydrogen bonds to layers in the $\left(\begin{array}{lll}0 & 0 & 1\end{array}\right)$ plane. Figure 4 shows the resulting hydrogen bond network. Table S9 summarizes all hydrogen bonds.

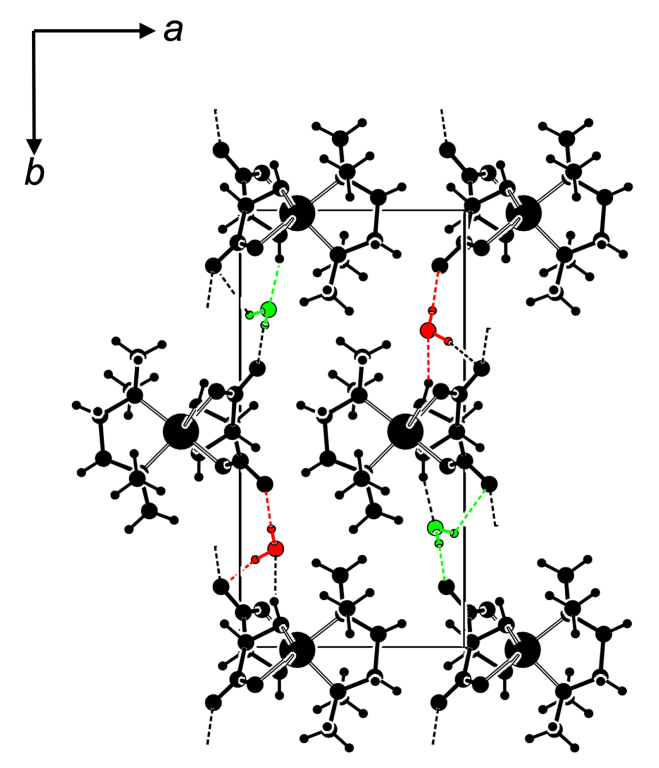

Figure 4. Hydrogen bonds in 2a (PLATON, [50]); [Cu(D-H $\mathrm{H}_{2}$ tart)(TMEDA) $]_{n}$ chains are shown in black, co-crystallized water molecules in green and red. 


\subsection{Compound $\mathbf{2 b}$}

In contrast to the reaction product with enantiopure tartaric acid, the derivative of meso-tartaric acid, $\mathbf{2 b}$, contains discrete, trinuclear complexes with the composition $\left[\mathrm{Cu}_{3} \text { (meso- } \mathrm{H}_{2} \text { tart)(meso-Htart)(TMEDA) }\right)_{2}$. Its central $\mathrm{Cu}$ cation occupies Wyckoff position $2 c$, a crystallographic inversion center, in the monoclinic space group $P 2_{1} / n$. Figure 5 visualizes the trinuclear complex: the carboxylato oxygen atom $\mathrm{O} 5$ and the bridging hydroxy $\mathrm{O} 4$ and their symmetry equivalents lead to a necessarily planar and almost regular all-oxygen coordination about $\mathrm{Cu} 1$. The peripheral $\mathrm{Cu}$ cations interact with the second carboxylato moiety and both hydroxy groups of the tartrate and the $\mathrm{N}, \mathrm{N}^{\prime}$ chelating TMEDA ligand in an overall distorted square-pyramidal coordination. A comparable tartrate coordination about $\mathrm{Cu}(\mathrm{II})$, with carboxylato $\mathrm{O}$ in the Jahn-Teller positions, has been found by Hörner and Klüfers [51]. Additional contacts occur between the $\mathrm{Cu}$ cations and significantly more distant $\mathrm{O}$ atoms; not only the interatomic separations of $3 \AA$ but also the angles subtended at the transition metal allow to exclude them from the coordination sphere (Figure 6).

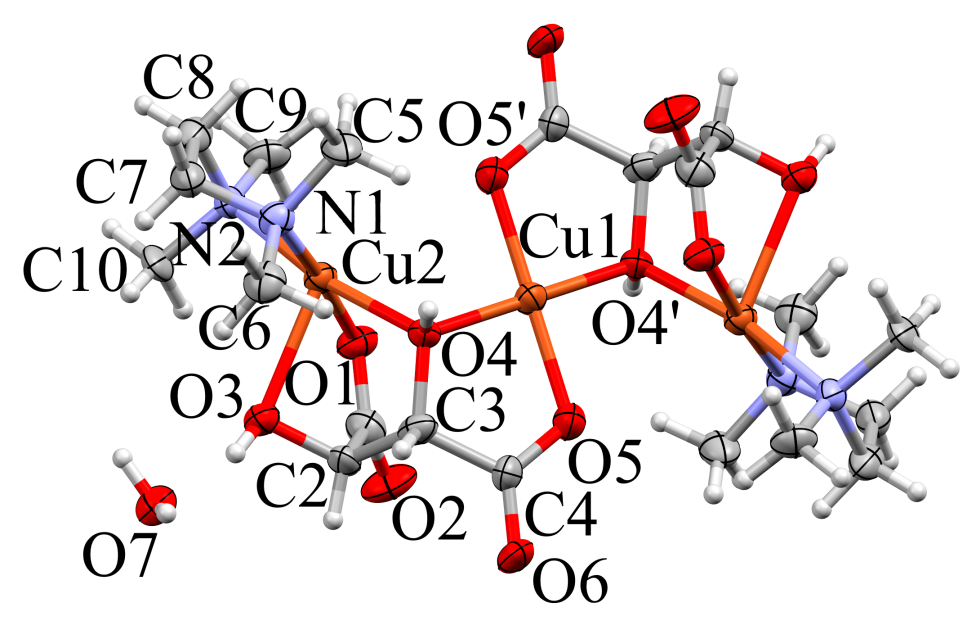

Figure 5. Trinuclear aggregate in the crystal structure of 2b (Mercury, [42]). Non-hydrogen atoms in the complex are shown as ellipsoids (70\% probability), $\mathrm{H}$ as spheres with fixed radius of $0.15 \AA$. Coordination distances $(\AA)$ : Cu1-O4' $=1.911(4), \mathrm{Cu} 1-\mathrm{O} 4=1.911(4), \mathrm{Cu} 1-\mathrm{O} 5=1.923(4)$, $\mathrm{Cu} 1-\mathrm{O} 5^{\prime}=1.923(4), \mathrm{Cu} 1 \cdots \mathrm{O} 1=3.088(5),{\mathrm{Cu} 1 \cdots \mathrm{O}^{\prime}}^{\prime}=3.088(5), \mathrm{Cu} 2-\mathrm{O} 4=1.965(4), \mathrm{Cu} 2-\mathrm{O} 1=1.974(5)$, $\mathrm{Cu} 2-\mathrm{N} 1=2.014(6), \mathrm{Cu} 2-\mathrm{N} 2=2.017(5), \mathrm{Cu} 2-\mathrm{O} 3=2.285(5), \mathrm{Cu} 2 \cdots \mathrm{O}^{\prime}=2.972(4)$. Symmetry codes: $\left({ }^{\prime}\right)=-x,-y+2,-z+1$.
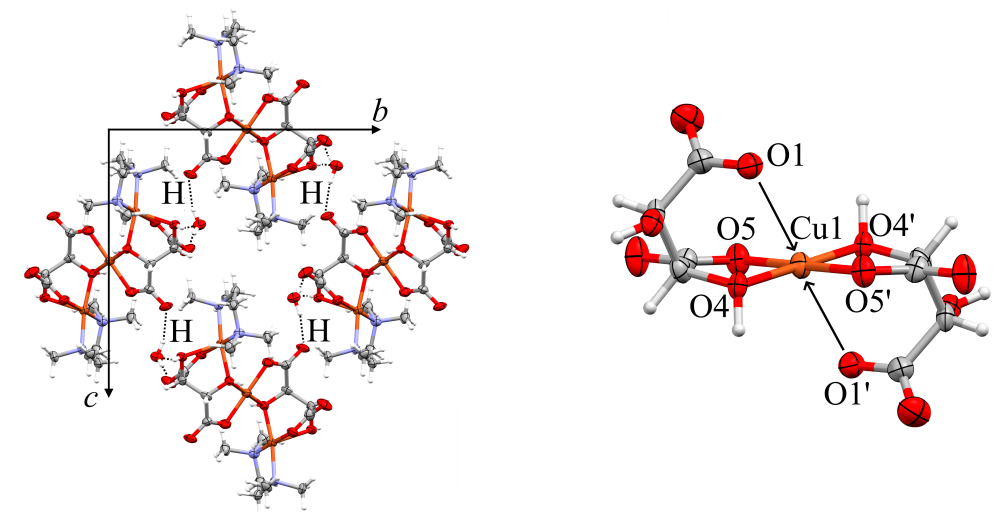

Figure 6. Left: Unit cell of $\mathbf{2 b}$ including intermolecular $\mathrm{H}$ bonds. Right: Excerpt of the crystal structure showing the square planar coordination around $\mathrm{Cu} 1$ and the far more distant $(>3 \AA$ ) oxygen neighbors $\mathrm{O} 1$ and $\mathrm{O} 1^{\prime}$. 
The symmetry equivalent atoms $\mathrm{O}^{\prime}, \mathrm{O}^{\prime}$ and $\mathrm{O}^{\prime}$ are generated via inversion at $\mathrm{Cu} 1$ (symmetry operator $-x,-y+2,-z+1$ ). The crystal structure is stabilized by a maximum of classical hydrogen bonds. All hydrogen atoms bonded to $\mathrm{N}$ or $\mathrm{O}$ find an electronegative acceptor at a suitable distance except for the hydrogen atom located at the bridging $\mathrm{O}$ atom O4, see discussion below. Table S10 summarizes all hydrogen bonds.

Our description of the trinuclear aggregate as $\left[\mathrm{Cu}_{3}\left(\right.\right.$ meso- $\left.\left.\mathrm{H}_{2} \operatorname{tart}\right)(m e s o-\mathrm{H} \operatorname{tart})(\mathrm{TMEDA})_{2}\right]$, with a bis- and a tris-deprotonated tartrate, is in obvious contradiction with the apparent crystallographic inversion symmetry and must be justified. In our present model, we assume the presence of a proton on one of the two equivalent sites next to the hydroxo $\mathrm{O}$ atoms $\mathrm{O} 4 / \mathrm{O}^{\prime}$. Full deprotonation of this group would lead to a stoichiometry of $\left.\left[\mathrm{Cu}_{3} \text { (meso-Htart }\right)_{2}(\mathrm{TMEDA})_{2}\right]$, with all $\mathrm{Cu}$ cations in oxidation state +II. This apparently obvious alternative, albeit well compatible with the structural result, can be safely excluded based on susceptibility measurements.

The corresponding data are shown in Figure 7 as $\chi_{\mathrm{m}} T$ vs. $T$ plot at $0.1 \mathrm{~T}$ and $M_{\mathrm{m}}$ vs. $B$ plot at $2.0 \mathrm{~K}$. The product $\chi_{\mathrm{m}} T$ and the magnetization $M$ allow to retrieve information about the effective magnetic moment of open-shell cations involved and about their interaction. At $290 \mathrm{~K}$, the value of $\chi_{\mathrm{m}} T$ is $0.92 \mathrm{~cm}^{3} \mathrm{~K} \mathrm{~mol}^{-1}$, which is well within the expected range of two, but not three non-interacting $\mathrm{Cu}$ (II) centers $\left(0.361-0.605 \mathrm{~cm}^{3} \mathrm{~K} \mathrm{~mol}^{-1}\right.$ per $\mathrm{Cu}$ (II) center [52]). Upon cooling the compound, the $\chi_{\mathrm{m}} T$ values continuously decrease reaching $0.87 \mathrm{~cm}^{3} \mathrm{~K} \mathrm{~mol}^{-1}$ at $25 \mathrm{~K}$, and subsequently drop off to $0.65 \mathrm{~cm}^{3} \mathrm{~K} \mathrm{~mol}^{-1}$ at $2.0 \mathrm{~K}$. Therefore, the $\chi_{\mathrm{m}} T$ vs. $T$ plot reveals an almost spin-like behavior and, due to the drop off at low temperatures at such a small field, a weak antiferromagnetic exchange interaction between the two $\mathrm{Cu}(\mathrm{II})$ centers, while the magnetic anisotropy should be rather small. In addition, the molar magnetization $M_{\mathrm{m}}$ as a function of the applied field $B$ at $2.0 \mathrm{~K}$ is in agreement with this observation: $M_{\mathrm{m}}$ is linear up to $2 \mathrm{~T}$ and increases with decreasing slope up to $5.0 \mathrm{~T}$. At this field, the magnetization reaches $1.9 N_{\mathrm{A}} \mu_{\mathrm{B}}$ without being saturated. This value is below the saturation value of about $2.2 N_{\mathrm{A}} \mu_{\mathrm{B}}$ estimated from the $\chi_{\mathrm{m}} T$ value at $290 \mathrm{~K}$ using $M_{\mathrm{m} \text {,sat }}=g_{\text {iso }} S N_{\mathrm{A}} \mu_{\mathrm{B}}$ per single center. Since additionally the linear part can be observed over a rather wide range at this temperature (about the double of non-interacting centers), the magnetization data suggest an antiferromagnetic exchange interaction between two $\mathrm{Cu}(\mathrm{II})$ centers. We use an effective isotropic Hamiltonian $\left(\hat{H}=\sum_{i=1}^{2} \mu_{\mathrm{B}} g_{\text {iso }} B \cdot S_{i}-2 J S_{1} \cdot S_{2}\right)$ to estimate the magnetic properties of the compound, and consider the deviation from the ideal spin-like system by a temperature independent paramagnetic contribution $\left(\chi_{\mathrm{m}, \mathrm{TIP}}\right)$ to the magnetic susceptibility [52]. The least-squares fit yields the red lines shown in Figure 7 and the parameters $\chi_{\mathrm{m}, \mathrm{TIP}}=(5.9 \pm 4.4) \times 10^{-5} \mathrm{~cm}^{3} \mathrm{~mol}^{-1}$ per $\mathrm{Cu}$ (II) center as well as $J=(-0.65 \pm 0.01) \mathrm{cm}^{-1}$ and $g_{\text {iso }}=2.17 \pm 0.01$. These parameters confirm a weak antiferromagnetic exchange interaction between the two $\mathrm{Cu}$ (II) centers with a common $g$-factor. Therefore, the magnetic data exclude three $\mathrm{Cu}$ (II) centers in $\mathbf{2} \mathbf{b}$, and the third copper center has to be of diamagnetic nature, e.g., $\mathrm{Cu}(\mathrm{I})$ or low spin $\mathrm{Cu}(\mathrm{III})$. 


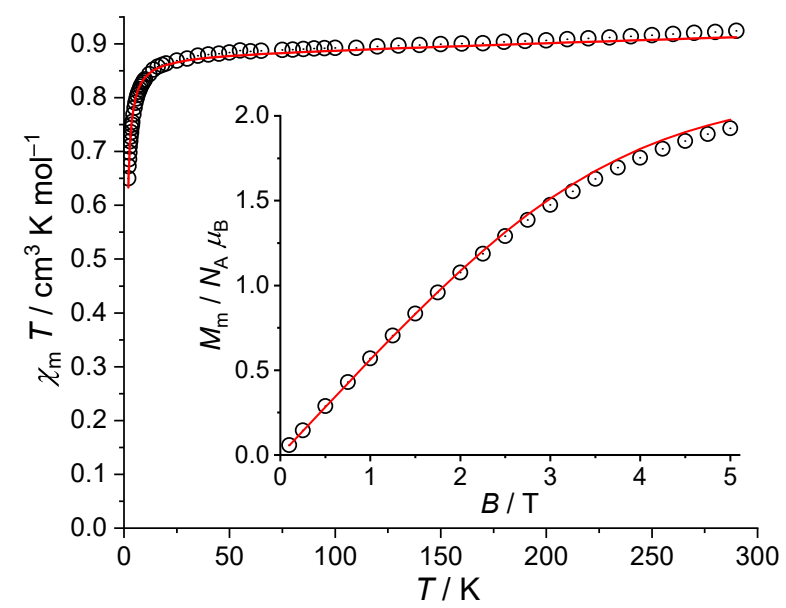

Figure 7. Temperature dependence of $\chi_{\mathrm{m}} T$ at $0.1 \mathrm{~T}$, and molar magnetization $M_{\mathrm{m}}$ vs. magnetic field $B$ at $2.0 \mathrm{~K}$ (inset) of $\mathbf{2 b}$ (symbols: experimental data, red line: least-squares fit to an isotropic effective spin Hamiltonian).

As the powder pattern for $\mathbf{2} \mathbf{b}$ (Figure 8) confirms the correspondence between the single crystal structure and the bulk, we must take the result of the susceptibility measurements into account for our structure model. The central $\mathrm{Cu} 1 \mathrm{can}$ therefore not be assigned oxidation state $+\mathrm{II}$. The higher oxidation number +III would require additional de-protonation of the tartrate ligand. However, the only available site carrying a potentially acidic hydrogen, $\mathrm{O} 3$, donates this $\mathrm{H}$ atoms in a short $\mathrm{O}-\mathrm{H} \cdots \mathrm{O}$ contact. In addition, low spin $\mathrm{Cu}$ (III) coordinated by four weak ligands is unprecedented, and tartaric acid should be considered a reducing rather than an oxidizing agent. In contrast, the alternative formulation of the trinuclear aggregate as $\left.\left[\mathrm{Cu}^{\mathrm{II}_{2}} \mathrm{Cu}^{\mathrm{I}}\left(\text { meso- } \mathrm{H}_{2} \text { tart }\right) \text { (meso-Htart)(TMEDA) }\right)_{2}\right]$ is compatible with all known facts: (a) the disordered proton on $\mathrm{O} 4$ is not involved in any short contact. (b) $\mathrm{Cu}(\mathrm{I})$ is a popular coordination center in the presence of weak ligands. (c) An aqueous solution of an amine and tartaric acid may well be responsible for partial reduction to a mixed-valent copper complex.

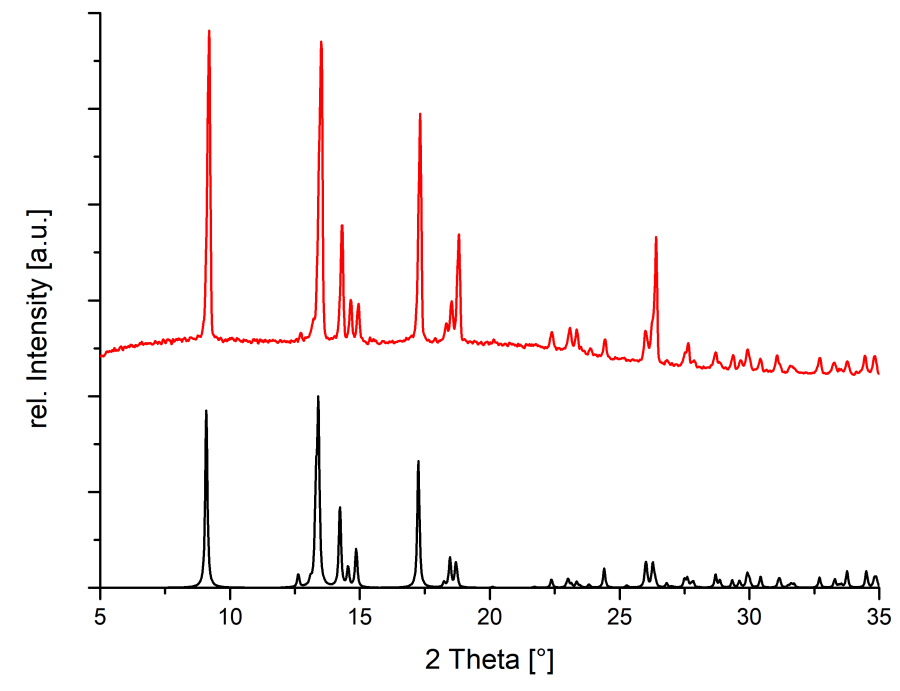

Figure 8. Measured (red) and calculated (black) powder diffraction pattern for $\mathbf{2 b}$.

$\mathbf{2 b}$ consists of discrete neutral molecules in the crystal and might in principle exist as a similar species in solution. The absorption spectra of $\mathbf{2} \mathbf{b}$ and copper(II) acetate are compared in Figure 9. Complexation by the dicarboxylic acid and the $\mathrm{N}, \mathrm{N}^{\prime}$ chelating ligand results in higher extinction and a shift of the absorption maximum. The latter corresponds to a visible color change from azure blue for copper acetate to a more navy blue hue during the reaction and to the color of the solid target product $\mathbf{2 b}$. 


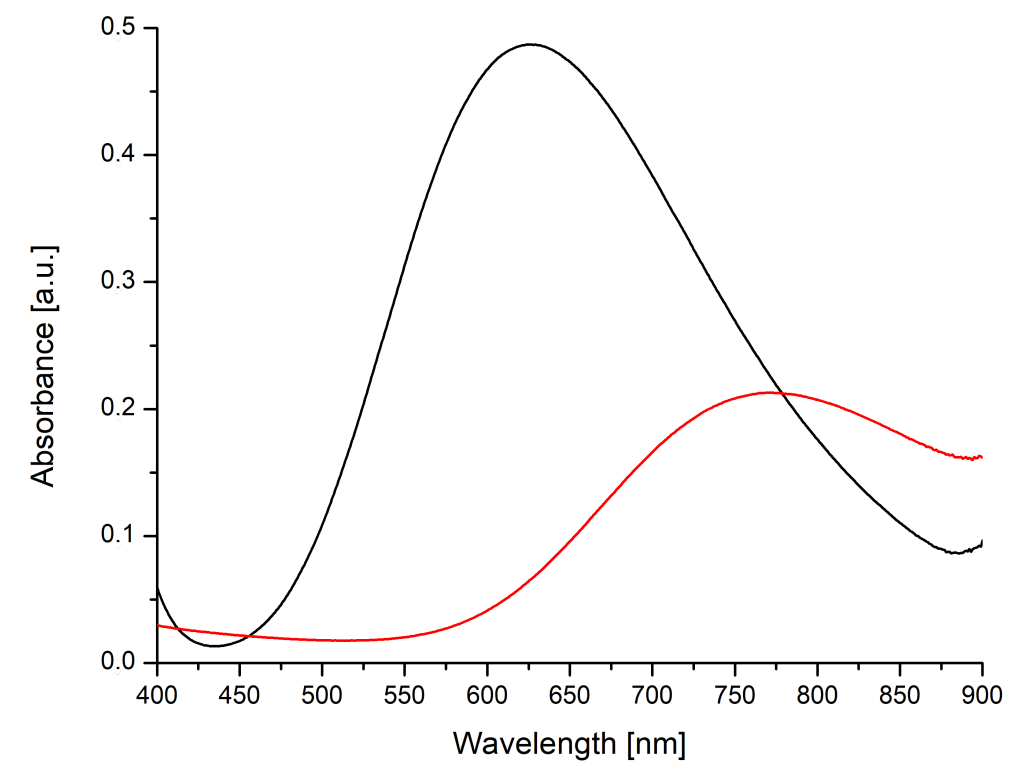

Figure 9. Vis spectra of $\mathbf{2 b}$ (black) and copper(II)-acetate (red); $c=1 \mathrm{mmol} \mathrm{L}^{-1}$.

\subsection{Compound $2 \mathrm{c}$}

The crystal structure of $2 \mathrm{c}$ contains one-dimensional $\left[\mathrm{Cu}\left(\mathrm{rac}-\mathrm{H}_{2} \mathrm{tart}\right)(\mathrm{TMEDA})\right]_{n}$ strands in $\left[\begin{array}{lll}1 & 0 & 0\end{array}\right]$ direction and co-crystallized water molecules. A section of a single chain is depicted in Figure 10: Both the $\mathrm{Cu}(\mathrm{II})$ cation and the midpoint of the $\mathrm{C} 2-\mathrm{C} 2{ }^{\prime}$ bond in the tartrate anion are located on two-fold crystallographic axes, and hence each polymer strand is homochiral. Crystallographic inversion in the orthorhombic space group Pccn necessarily implies an overall racemic structure, with neighboring strands of opposite chirality.

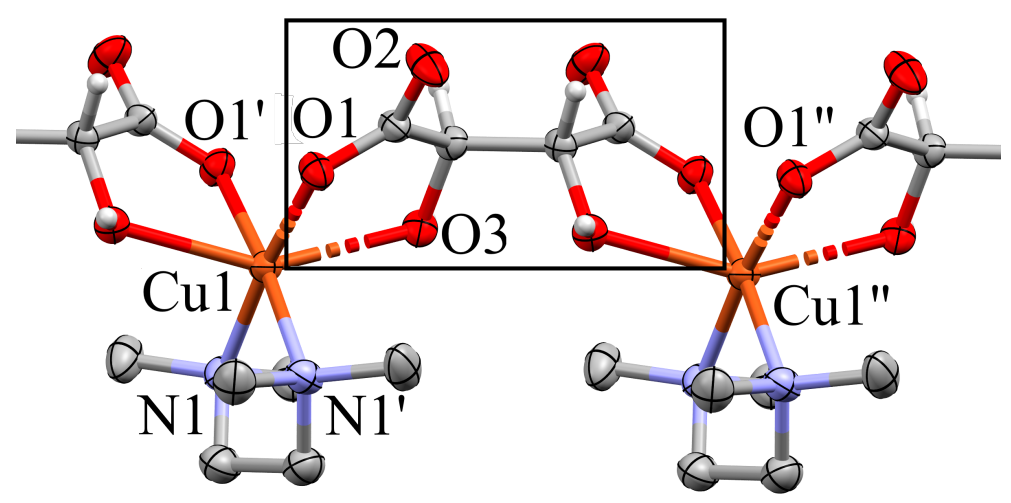

Figure 10. Section of a homochiral chain in 2c (Mercury, [42]); H atoms in the tetramethylethylenediamine (TMEDA) ligand have been omitted. Non-hydrogen atoms in the complex are shown as ellipsoids (70\% probability), $\mathrm{H}$ as spheres with fixed radius of $0.15 \AA$. Coordination distances $(\AA)$ : Cu1-O1 = 1.9740(14), Cu1-O1 ${ }^{\prime}=1.9740(14), \mathrm{Cu} 1-\mathrm{N} 1=2.0557(16) \mathrm{Cu} 1-\mathrm{N} 1^{\prime}=2.0557(16)$, $\mathrm{Cu} 1-\mathrm{O} 3=2.364(2), \mathrm{Cu} 1-\mathrm{O}^{\prime}=2.365(2)$. Symmetry operators: $\left({ }^{\prime}\right)=3 / 2-x, 3 / 2-y, z ;\left(^{\prime \prime}\right)=x-1, y, z$.

The $\mathrm{Cu}(\mathrm{II})$ cation features an elongated Jahn-Teller octahedron in which the $\mathrm{N}, \mathrm{N}^{\prime}$ TMEDA chelate and the carboxylato $\mathrm{O}$ atoms $\mathrm{O} 1$ and $\mathrm{O}^{\prime}$ act as equatorial ligands and the two hydroxy atoms $\mathrm{O} 3$ and $\mathrm{O}^{\prime}$ occupy the more distant axial positions. With its $\left[\mathrm{Cu}\left(\mathrm{rac}-\mathrm{H}_{2} \operatorname{tart}\right)(\mathrm{TMEDA})\right]_{n}$ formula unit is associated one molecule of co-crystallized water, in agreement with the microanalytical data. This co-crystallized water connects neighboring chains along [0 10 ], and thus leads to a layer structure in the $\left(\begin{array}{lll}0 & 0 & 1\end{array}\right)$ plane. Table S11 summarizes all hydrogen bonds. 


\subsection{Compound 3a}

In 3a, one-dimensional strands extend in $\left[\begin{array}{lll}1 & 0 & 0\end{array}\right]$ direction; single crystal diffraction and microanalytical data agree about their composition $\left[\mathrm{Cu}(\mathrm{dptta})(\mathrm{EtOH})\left(\mathrm{H}_{2} \mathrm{O}\right)_{2}\right]_{n}$. The asymmetric unit of space group $P 2{ }_{1}$ contains a single chain link and is depicted in Figure 11. Its $\mathrm{Cu}$ (II) center is five-coordinated, with two aqua ligands $\mathrm{O} 11$ and $\mathrm{O} 10$ and by the carboxylate $\mathrm{O}$ atoms $\mathrm{O} 8$ and $\mathrm{O} 8^{\prime \prime}$ in equatorial and the ethanol $\mathrm{O}$ atom $\mathrm{O} 9$ in apical position. The crystal structure is stabilized by a maximum of $\mathrm{O}-\mathrm{H} \cdots \mathrm{O}$ hydrogen bonds which connect the constituents to layers in the $\left(\begin{array}{ll}0 & 0\end{array}\right)$ plane. Table S12 summarizes the classical hydrogen bonds. Adjacent H-bonded layers interact along [0 001$]$ via T stacking, with shortest C...C distances of $3.7 \AA$.

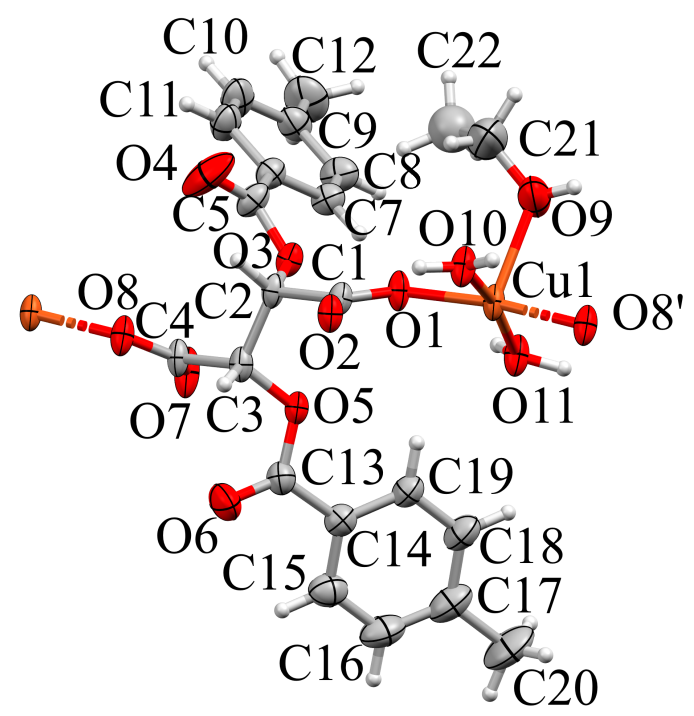

Figure 11. Expanded asymmetric unit of 3a (Mercury, [42]). Non-hydrogen atoms in the complex are shown as ellipsoids (70\% probability), $\mathrm{H}$ as spheres with fixed radius of $0.15 \AA$. The disordered carbon Atom C22 was refined isotropically. Coordination distances $(\AA)$ : Cu1-O10 = 1.939(2), Cu1-O1 = 1.950(2), $\mathrm{Cu} 1-\mathrm{O}^{\prime \prime}=1.958(2), \mathrm{Cu} 1-\mathrm{O} 11=1.961(3), \mathrm{Cu} 1-\mathrm{O} 9=2.227(3)$. Symmetry codes: $\left({ }^{\prime}\right)=x+1, y, z$, $\left({ }^{\prime \prime}\right)=x-1, y, z$.

\subsection{Compound $\mathbf{3 b}$}

The structure determination of $\mathbf{3 b}$ proved to be challenging. Diffraction patterns of several crystals were registered in our home laboratory and could be indexed with a single orientation matrix. They gave an apparently orthorhombic unit cell, with approximate cell dimensions $a=5.6005(12)$, $b=22.351(5), c=33.354(7) \AA$, in agreement with four formula units of $\left[\mathrm{Cu}(\mathrm{Hdbta})_{2}\left(\mathrm{H}_{2} \mathrm{O}\right)_{4}\right]$ $(\mathrm{Hdbta}=$ mono protonated dibenzoyltartrate $)$ per unit cell. The phase problem could, however, only be solved in the monoclinic space group $P 2_{1}$, probably indicating pseudo-merohedral twinning. The metric of the unit cell, with an angle $\beta$ of $90.047(6)^{\circ}$, may fit either crystal system. Even when the twin law was taken into account, only an incomplete structure model with unsatisfactory displacement parameters and high residuals could be derived in the monoclinic space group. This preliminary model suggests formation of discrete $\left[\mathrm{Cu}(\mathrm{Hdbta})_{2}\left(\mathrm{H}_{2} \mathrm{O}\right)_{4}\right]$ coordination compounds and has been tentatively depicted in (Figure 12). We will repeat diffraction experiments on smaller crystals of this compound at a synchrotron source. We note, however, that the powder pattern of the bulk closely corresponds to the simulation based on our incomplete and preliminary model (Figure 13). 


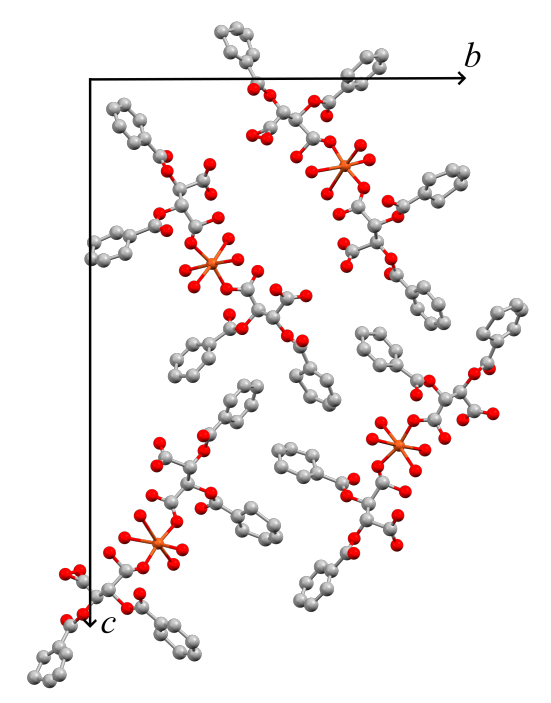

Figure 12. Unit cell of an incomplete preliminary structure model for $\mathbf{3 b}$ (Mercury [42], viewed along $\left[\begin{array}{lll}1 & 0 & 0\end{array}\right]$ direction; atoms shown as spheres with fixed radius).

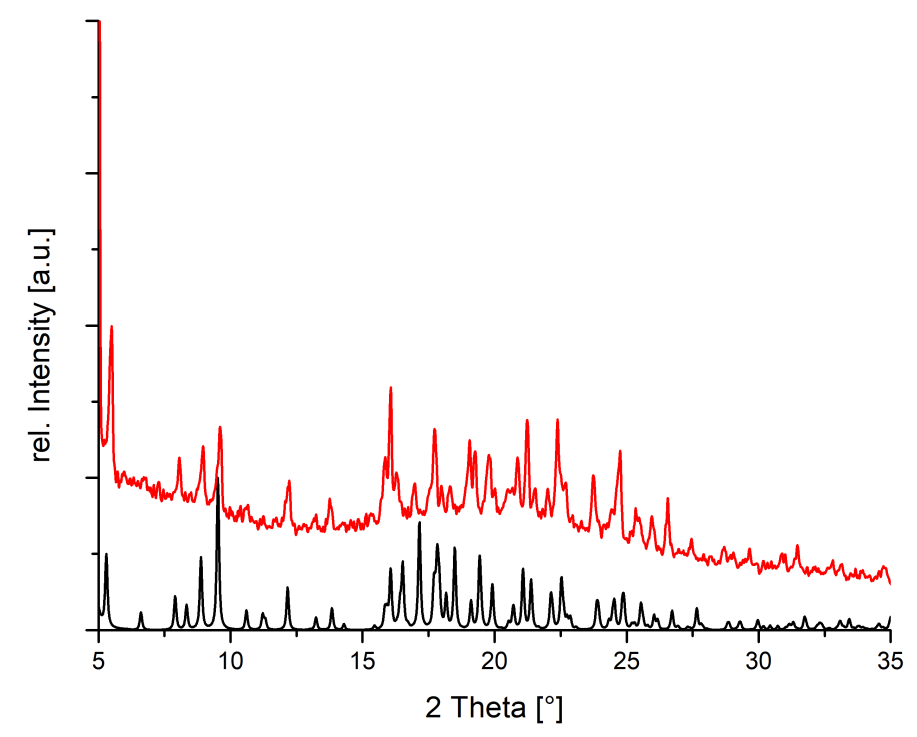

Figure 13. Measured (red) and calculated (black) powder diffraction pattern for compound $\mathbf{3 b}$.

In $\mathbf{3 b}$ as well as in its starting material, the $\mathrm{Cu}(\mathrm{II})$ cations are exclusively oxygen coordinated. It is therefore no surprise that the ligand fields and hence the absorption maxima for both compounds in the vis spectra (Figure 14) almost coincide. 


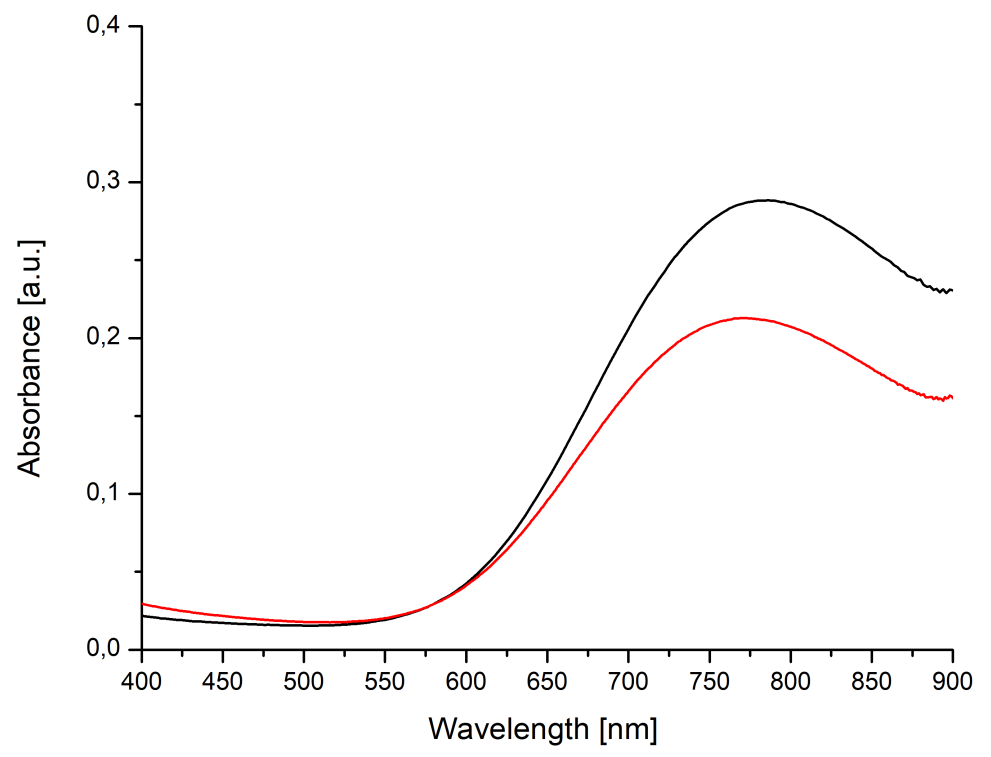

Figure 14. Vis spectra of $\mathbf{3 b}$ (black, $\left.c=10 \mathrm{mmol} \mathrm{L}^{-1}\right)$ and copper(II)-acetate (red, $\left.c=1 \mathrm{mmol} \mathrm{L}^{-1}\right)$.

\section{Conlusions: Structural Trends and Construction Principles}

How do the individual structures reported here fit into a broader scientific context, and to what extent might certain features be predicted or derived from related compounds? In the absence of any blocking ligands, $\mathrm{Cu}$ (II) aspartate represents a chain polymer [53]. AMPY in $\mathbf{1}$ and several alternative chelates mentioned above block the extension along the chain and lead to discrete complexes. In contrast to the idea of dimensional reduction [54] outlined below, the aminodicarboxylate adopts a different binding mode about the $\mathrm{Cu}$ (II) center.

In the presence of simple dicarboxylic acids even without additional functional groups, $\mathrm{Cu}$ (II) cations aggregate to coordination polymers. The prototypic oxalate provides examples for this behaviour: with $\mathrm{Cu}(\mathrm{II})$, it forms the one-dimensional chain polymers catena- $\mu$-oxalatodiaquacopper(II) monohydrate [55], catena-(bis- $\mu$-hydrogenoxalato)diaqua-bis(hydrogenoxalato)dicopper(II) hexahydrate [56] and catena- $\mu$-oxalatodiaquacopper(II) [57]. Succinic acid represents the simplest 1,4-dicarboxylic acid. In combination with $\mathrm{Cu}(\mathrm{II})$, it allows for extended structures in one dimension [58,59] and for higher dimensional networks [60,61]. Obviously, the large substituents in di-para-toluyltartrate restrict the connectivity in the structure of $3 a$ to extension in one dimension.

The concept of dimensional reduction was introduced by Long and has been comprehensively summarized in a review article [54]. Simply spoken, it suggests to cut out sections of higher-dimensional frameworks, leading to aggregates of lower dimensionality which retain essential features of the coordination. This concept provides insight into our solids $2 \mathbf{a}$ and $2 \mathbf{c}$ derived from enantiopure and racemic tartaric acid, respectively. The close relationship between $2 \mathbf{a}$ and $\mathbf{2} \mathbf{c}$ has already been explained: $2 \mathbf{a}$ is based on enantiopure tartrate and, hence, necessarily homochiral. The racemic analogue $2 \mathrm{c}$ is composed of homochiral strands of opposite chirality. In both solids, each tartrate dianion acts as a bridging chelate, with each carboxylate and its neighboring hydroxy group coordinating a $\mathrm{Cu}(\mathrm{II})$ cation. This coordination is highlighted by the rectangular frame around the ligand in Figure 10 and occurs in a related compound: the reaction product of enantiopure tartrate and $\mathrm{Cu}(\mathrm{II})$ without any additional chelating ligand, $\left[\mathrm{Cu}\left(\mathrm{H}_{2} \operatorname{tart}\right)\left(\mathrm{OH}_{2}\right) \cdot 2 \mathrm{H}_{2} \mathrm{O}\right]_{n}$ [62] is a two-dimensional solid and shows very similar bridging functionality for the dicarboxylate. In $\mathbf{2 a}$ and $2 c$, the blocking ligand TMEDA reduces the connectivity from 2D to 1D.

Future work will focus on the unexpected mixed valence encountered in $\mathbf{2 b}$ and expansion of the research to include different dicarboxylic acids and blocking ligands. 


\section{Materials and Methods}

\subsection{Synthesis and Crystallization}

\subsubsection{Compound 1}

Aspartic acid (13.3 mg, $0.1 \mathrm{mmol}, 1 \mathrm{eq})$ and copper(II) acetate $\cdot 2 \mathrm{H}_{2} \mathrm{O}(21.8 \mathrm{mg}, 0.1 \mathrm{mmol}, 1$ eq) were dissolved at $50{ }^{\circ} \mathrm{C}$ in $10 \mathrm{~mL}$ of water. AMPY $(10.8 \mathrm{mg}, 10.3 \mu \mathrm{L}, 0.1 \mathrm{mmol}, 1 \mathrm{eq})$ was added to the solution and stirred at $50{ }^{\circ} \mathrm{C}$ for $2 \mathrm{~h}$. A total of $3 \mathrm{~mL}$ of the reaction mixture were placed on a petri dish and $6 \mathrm{~mL}$ of a mixture of DMF, DMSO, MeCN (1:1:1) were added. After three days, suitable crystals were observed after evaporation of the $\mathrm{MeCN}$ and part of the DMF. Yield from several syntheses: 90-100\%. Elemental analysis calculated for 1: [Cu(AMPY) $\left.(\operatorname{asp})\left(\mathrm{H}_{2} \mathrm{O}\right)\right] \cdot 0.6 \mathrm{H}_{2} \mathrm{O}: \mathrm{C} 36.22 \%$, $\mathrm{H} 4.92 \%, \mathrm{~N} 12.67 \%$; found: C 36.60\%, H 4.73\%, N 12.63\%. A few crystals more suitable for diffraction experiments were obtained by adding DMSO with its higher boiling point to a small amount of the above solution.

\subsubsection{Compounds $2 \mathrm{a} / \mathrm{b} / \mathrm{c}$}

Copper tartrate (D/rac/meso) (21 mg, $0.1 \mathrm{mmol}$ ) was added to $50 \mathrm{~mL}$ of $\mathrm{H}_{2} \mathrm{O}$. Dry copper tartrate is not soluble in water but forms a suspension. While stirring this suspension, tetramethylethylenediamine $\mathrm{C}_{6} \mathrm{H}_{16} \mathrm{~N}_{2}$ (TMEDA) $(15 \mu \mathrm{L}, 0.1 \mathrm{mmol})$ was added. The suspension turned dark blue, and the solid dissolved completely after a few minutes of stirring. The water was removed under reduced pressure and the remaining solid was dried over night. Single crystals were obtained by removing approx. $70 \%$ of the solvent under reduced pressure, and slow evaporation of the remaining solution at room temperature and ambient pressure. Yields from several syntheses for $\mathbf{2 a}$ and $\mathbf{2 c}$ : $60-70 \%$ Yield for $\mathbf{2 b}$ : ca $20 \%$ (imprecise, see analytical data below). Elemental analysis calculated for 2a: $\left[\mathrm{Cu}\left(\mathrm{D}-\mathrm{H}_{2} \text { tart)(TMEDA) }\right]_{n} \cdot 2 \mathrm{H}_{2} \mathrm{O}: \mathrm{C} 33.01 \%, \mathrm{H} 6.65 \%, \mathrm{~N} 7.70 \%\right.$; found: C $32.92 \%, \mathrm{H} 6.48 \%, \mathrm{~N} 7.76 \%$. No matching analytical data for $\mathbf{2} \mathbf{b}$ could be obtained because the compound loses one equivalent of TMEDA when dried in vacuo. Elemental analysis calculated for the TMEDA deficient product:

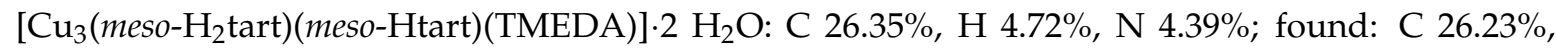
$\mathrm{H} 4.23 \%, \mathrm{~N} 4.50 \%$. The product could therefore not be completely dried, and no precise yield can be given. The powder pattern (Figure 8), however, confirms that the microcrystalline solid corresponds to the established structure. Elemental analysis calculated for $2 \mathrm{c}:\left[\mathrm{Cu}\left(\mathrm{rac}-\mathrm{H}_{2} \operatorname{tart}\right)(\mathrm{TMEDA})\right]_{n} \cdot 2 \mathrm{H}_{2} \mathrm{O}$ : C $33.01 \%$, H 6.65\%, N 7.70\%; found: C 33.15\%, H 6.66\%, N 7.69\%.

\subsubsection{Compounds $3 \mathbf{a} / 3 \mathbf{b}$}

Di-para-toluyltartaric acid (385 mg, $1 \mathrm{mmol}$ ) or dibenzoyltartaric acid (360 mg, $1 \mathrm{mmol}$ ) was dissolved in $50 \mathrm{~mL}$ of $\mathrm{H}_{2} \mathrm{O}$. $\mathrm{Cu}\left(\mathrm{CH}_{3} \mathrm{COO}\right)_{2} \cdot 2 \mathrm{H}_{2} \mathrm{O}(200 \mathrm{mg}, 1 \mathrm{mmol})$ was added to the solution and stirred at room temperature for $1 \mathrm{~h}$. The water was removed under reduced pressure and the remaining solid was dried over night. Single crystals were obtained by removing approx. $70 \%$ of the solvent under reduced pressure, and letting the remaining solution slowly evaporate at room temperature and ambient pressure. Single crystals could also be synthesized through liquid diffusion: The tartaric acid derivatives were solved in $2 \mathrm{~mL}$ of ethanol, and the copper acetate in $2 \mathrm{~mL} \mathrm{H}_{2} \mathrm{O}$. The ethanolic solution was layered on top of the aqueous solution in a test tube. Crystals formed after several hours. Yield 3a: $28 \%$. Elemental analysis calculated for 3a: $\left[\mathrm{Cu}(\mathrm{dptta})(\mathrm{EtOH})\left(\mathrm{H}_{2} \mathrm{O}\right)_{2}\right]_{n}: \mathrm{C} 49.86 \%, \mathrm{H} 4.95 \%$, N $0.0 \%$; found: C $51.01 \%, \mathrm{H} 4.98 \%, \mathrm{~N} 0.0 \%$.

For the structurally characterized compounds 1 (Figure S1), 2a (Figure S2), 2b (Figure 8), 2c (Figure S3) and 3a (Figure S4) powder patterns confirmed that bulk and single crystals essentially share the same structure. The monoclinic angle in $2 \mathbf{a}$ is very close to $90^{\circ}$; a very small temperature-dependent increase of this angle will result in a pronounced separation of the (at $100 \mathrm{~K}$ almost co-inciding) reflections 111 and $11-1$ around $2 \vartheta$ ca. $18^{\circ}$. This effect is explained in Figure S2. The powder pattern 
(Figure 13) also confirms that the basic structural features of our preliminary structure model for $\mathbf{3 b}$ are correct.

\subsection{Single Crystal X-ray Diffraction}

\subsubsection{Data Collection}

All diffraction experiments were performed at $100 \mathrm{~K}$. Single crystals of $\mathbf{1}$ and $\mathbf{2 b}$ were sufficiently well-diffracting for in-house diffraction experiments on our Bruker D8 diffractometer equipped with a Smart APEX CCD detector and an I $\mu$ S microsource (Mo $\mathrm{K}_{\alpha}$ radiation, $\lambda=0.71073 \AA$, multilayer optics). Data were integrated with SAINT $+[63]$ and a multi-scan adsorption correction was performed using SADABS [64]. Intensity data for $\mathbf{2 a}, \mathbf{2} \mathbf{c}$ and $\mathbf{3 a}$ were collected at the beamline P24 at PETRA-III of the German Electron Synchrotron (DESY) in Hamburg. Measurements were performed on a kappa diffractometer with a Dectris PILATUS3 X CdTe for Synchrotron detector at an energy of $20.0 \mathrm{keV}((\lambda=0.61992 \AA), \operatorname{Si}(111)$ double crystal monochromator). XDS [65,66] was used for reflection harvesting, unit cell determination and integration of the data.

\subsubsection{Structure Solution and Refinement}

The structures were solved by intrinsic phasing [67] and refined by full-matrix least-squares procedures based on $F^{2}$, using all independent reflections [68]. Crystal data, data collection parameters and convergence results for the single crystal X-ray diffraction experiments have been summarized in Table S1. Non-hydrogen atoms were assigned anisotropic displacement parameters unless stated otherwise. $\mathrm{H}$ atoms attached to carbon were introduced into calculated positions and treated as riding, with isotropic displacement parameters constrained to multiples of $U_{\mathrm{eq}}$ of their parent atom. Where data quality was sufficient, hydrogen atoms attached to $\mathrm{N}$ or $\mathrm{O}$ were refined freely. Further details of structure refinements are available in the Supporting Information. The crystal structures of 1, 2a-c and 3a have been deposited in the Cambridge Structural Database (Deposition numbers 1997343-1997347).

\subsection{Powder Diffraction}

X-ray powder diffraction experiments were performed at ambient temperature on flat samples with a Stoe and Cie STADI P diffractometer equipped with an imageplate detector with constant $\omega$ angle of $55^{\circ}$ using germanium-monochromated $\mathrm{Cu}-K_{\alpha 1}$ radiation $(\lambda=1.54059 \AA)$.

\subsection{Magnetic Measurements}

Magnetic susceptibility data of $\mathbf{2} \mathbf{b}$ were obtained using a Quantum Design MPMS-5XL SQUID magnetometer. The polycrystalline sample was compacted and immobilized into cylindrical PTFE capsules. The data were acquired as a function of field $(0-5.0 \mathrm{~T}$ at $2.0 \mathrm{~K})$ and temperature $(2.0-290 \mathrm{~K}$ at $0.1 \mathrm{~T})$, and corrected for diamagnetic contributions from the sample holder and the compound $\left(\chi_{\mathrm{m}, \mathrm{dia}}=-3.77 \times 10^{-4} \mathrm{~cm}^{3} \mathrm{~mol}^{-1}\right)$.

\subsection{Absorption Spectroscopy}

Absorption spectroscopy was performed on a Shimadzu UV-2600 UV-Vis Spectrophotometer.

\subsection{Database Survey}

Our database surveys were conducted with Version 5.41 of the CSD [44], including the updates of November 2019, and restricted to error-free entries without disorder for which atomic coordinates were available. 
Supplementary Materials: The following are available online at http:/ /www.mdpi.com/2073-4352/10/6/485/s1. Table S1: Crystal data and refinement, Table S2: Bond length and $U_{\text {iso }}(H)$ for carbon bonded Hydrogen, Tables S3-S7: Selected geometric parameters $\left(\AA^{\circ},{ }^{\circ}\right)$ for $1-3 a$, Tables S8-S12: Hydrogen-bond geometry $\left(\AA^{\circ},{ }^{\circ}\right)$ in $1-3 \mathbf{a}$, Figures S1-S4: Measured and calculated powder diffraction patterns for 1, 2a, 2c and 3a, S1.3.: Refinement Details.

Author Contributions: M.K. is responsible for the syntheses and structural characterization in the context of his doctoral dissertation. J.v.L. interpreted the susceptibility measurements. U.E. is supervisor of the doctoral dissertation and contributed to the structural characterization. The authors jointly wrote the manuscript. All authors have read and agreed to the published version of the manuscript.

Funding: This research was funded by DESY (beam time and travel grants to M.K. and U.E.) and by support from the One Hundred-Talent Program of Shanxi Province.

Acknowledgments: The authors acknowledge the help of Carsten Paulmann with data collection at the DESY beamline P24, Ina Stickeler and John Kollath for synthetic work and the staff of the chemical institutes of RWTH Aachen University for technical assistance. We are grateful to Irmgard Kalf for help with our analytical characterizations and with the manuscript.

Conflicts of Interest: The authors declare no conflict of interest.

\section{Abbreviations}

The following abbreviations are used in this manuscript:

TMEDA tetramethylethylenediamine

AMPY 2-aminomethylpyridine

$\mathrm{H}_{2}$ dptta di-para-toluoyltartaric acid

dptta di-para-toluoyltartrate

$\mathrm{H}_{2}$ dbta dibenzoyltartaric acid

HDBTA mono protonated dibenzoyltartrate

$\mathrm{H}_{4}$ tart tartaric acid

$\mathrm{H}_{2}$ tart tartrate

$\mathrm{H}_{2}$ asp aspartic acid

asp aspartate

EtOH Ethanol

\section{References}

1. van Niekerk, J.N.; Schoening, F.R.L. The crystal structures of nickel acetate, $\mathrm{Ni}\left(\mathrm{CH}_{3} \mathrm{COO}\right)_{2} \cdot 4 \mathrm{H}_{2} \mathrm{O}$, and cobalt acetate, $\mathrm{Co}\left(\mathrm{CH}_{3} \mathrm{COO}\right)_{2} \cdot 4 \mathrm{H}_{2} \mathrm{O}$. Acta Crystallogr. 1953, 6, 609-612. [CrossRef]

2. van Niekerk, J.N.; Schoening, F.R.L.; Talbot, J.H. The crystal structure of zinc acetate dihydrate, $\mathrm{Zn}\left(\mathrm{CH}_{3} \mathrm{COO}\right)_{2} \cdot 2 \mathrm{H}_{2} \mathrm{O}$. Acta Crystallogr. 1953, 6, 720-723. [CrossRef]

3. van Niekerk, J.N.; Schoening, F.R.L. A new type of copper complex as found in the crystal structure of cupric acetate, $\mathrm{Cu}_{2}\left(\mathrm{CH}_{3} \mathrm{COO}\right)_{4} \cdot 2 \mathrm{H}_{2} \mathrm{O}$. Acta Crystallogr. 1953, 6, 227-232. [CrossRef]

4. Gu, J.; Wen, M.; Liang, X.; Shi, Z.; Kirillova, M.V.; Kirillov, A.M. Multifunctional Aromatic Carboxylic Acids as Versatile Building Blocks for Hydrothermal Design of Coordination Polymers. Crystals 2018, 8, 83. [CrossRef]

5. Hu, C.; Englert, U. Crystal-to-Crystal Transformation from a Chain Polymer to a Two-Dimensional Network at Low Temperatures. Angew. Chem. Int. Ed. 2005, 44, 2281-2283. doi:10.1002/anie.200462100. [CrossRef] [PubMed]

6. Hu, C.; Englert, U. Space Filling Versus Symmetry: Two Consecutive Crystal-to-Crystal Phase Transitions in a 2D Network. Angew. Chem. Int. Ed. 2006, 45, 3457-3459. [CrossRef] [PubMed]

7. Lamberts, K.; Kalf, I.; Ramadan, A.; Müller, P.; Dronskowski, R.; Englert, U. Tunable Crystal-to-Crystal Phase Transition in a Cadmium Halide Chain Polymer. Polymers 2011, 3, 1151-1161. [CrossRef]

8. Guo, Q.; Merkens, C.; Si, R.; Englert, U. Crosslinking of the $\operatorname{Pd}(\operatorname{acacCN})_{2}$ building unit with $\mathrm{Ag}(\mathrm{I})$ salts: dynamic 1D polymers and an extended 3D network. CrystEngComm 2015, 17, 4383-4393. [CrossRef]

9. Kalf, I.; Mathieu, P.; Englert, U. From crystal to crystal: A new polymorph of (4-carboxylatopyridine)silver(i) by topotactic dehydration of its monohydrate. New J. Chem. 2010, 34, 2491-2495. [CrossRef] 
10. Truong, K.N.; Müller, P.; Dronskowski, R.; Englert, U. Dynamic Uptake and Release of Water in the Mixed-Metal EDTA Complex $\mathrm{M}_{3}\left[\mathrm{Yb}(\mathrm{EDTA})\left(\mathrm{CO}_{3}\right)\right](\mathrm{M}=\mathrm{K}, \mathrm{Rb}, \mathrm{Cs})$. Cryst. Growth Des. 2017, 17, 80-88. [CrossRef]

11. Generally Recognized as Safe (GRAS). Available online: https://www.fda.gov/food/food-ingredientspackaging/generally-recognized-safe-gras (accessed on 5 June 2020).

12. Głowiak, Z.; Ciunik, Z. The crysral structure of bis(DL-valine) calcium chloride dihydrate and bis(DL-2-Aminobutyric Acid) calcium chloride dihydrate. Bull. Acad. Pol. Sci. Ser. Sci. Chim. 1978, 26, 43-51.

13. Ciunik, Z.; Głowiak, T. Glycinemanganese(II) dichloride dihydrate [catena-diaquadichloro- $\mu$-glycinemanganese(II)]. Acta Crystallogr. B 1980, 36, 1212-1213. [CrossRef]

14. Ciunik, Z.; Glowiak, Z. Conformational analysis of double carboxylic bridges in bis(DL- $\alpha$-alanine)manganese(II) dibromide dihydrate and related compounds. Inorg. Chim. Acta 1980, 44, L249-L250. [CrossRef]

15. Bissinger, H.; Beck, W. Metal Complexes with Biologically Important Ligands, XXXIX [1] Platinum(IV) Complexes with a-Amino Acid Esters and Peptide Esters; 13N and 14r,Pt NMR Spectra of Platinum Complexes with a-Amino Acids. Z. Naturforsch. B 1985, 40, 507-11. [CrossRef]

16. Glowiak, T.; Legendziewicz, J.; Dao, C.; Huskowska, E. Absorption, luminescence and crystal structure studies of dysprosium compound with l- $\alpha$-Alanine: [Dy $\left.(\mathrm{l}-\alpha-\mathrm{AlaH})\left(\mathrm{H}_{2} \mathrm{O}\right)_{6}\right] \mathrm{Cl}_{3}$. J. Less Common Met. 1991, 168, 237-248. [CrossRef]

17. Nolan, K.B.; Soudi, A.A.; Hay, R.W. Metal complexes of amino acids and peptides. In Amino Acids, Peptides and Proteins; Davies, J.S., Ed.; The Royal Society of Chemistry: London, UK, 1994; Volume 25, pp. 359-410.

18. Severin, K.; Bergs, R.; Beck, W. Bioorganometallic Chemistry - Transition Metal Complexes with $\alpha$-Amino Acids and Peptides. Angew. Chem. Int. Ed. 1998, 37, 1634-1654. [CrossRef]

19. Mrozek, R.; Rzaczynska, Z.; Sikorska-Iwan, M.; Jaroniec, M.; Głowiak, T. A new complex of manganese(II) with 1- $\alpha$-alanine: Structure, spectroscopy and thermal study. Polyhedron 1999, 18, 2321-2326. [CrossRef]

20. Wang, R.; Liu, H.; Carducci, M.D.; Jin, T.; Zheng, C.; Zheng, Z. Lanthanide Coordination with $\alpha$-Amino Acids under Near Physiological pH Conditions: Polymetallic Complexes Containing the Cubane-Like $\left[\mathrm{Ln}_{4}\left(\mu_{3}-\mathrm{OH}\right)_{4}\right]^{8+}$ Cluster Core. Inorg. Chem. 2001, 40, 2743-2750. [CrossRef]

21. Slyudkin, O.; Tulupov, A. Chiral complexes of Pt with amino acids: Synthesis, structure, properties. Russ. J. Coord. Chem. 2005, 31, 77-85. [CrossRef]

22. Farkas, E.; Sovago, I. Metal complexes of amino acids and peptides. Amino Acids Peptides Proteins 2007, 36, 287-345.

23. Fleck, M. Compounds of glycine with halogen or metal halogenides: Review and comparison. Z. Kristallogr. Cryst. Mater. 2008, 223, 222-232. [CrossRef]

24. Fleck, M.; Held, P.; Schwendtner, K.; Bohatý, L. New compounds of glycine with metal halogenides. Z. Kristallogr. Cryst. Mater. 2008, 223, 212-221. [CrossRef]

25. Weng, Z.; Chen, Z.; Liang, F. Glycine-Templated Manganese Sulfate with New Topology and Canted Antiferromagnetism. Inorg. Chem. 2009, 48, 8703-8708. [CrossRef] [PubMed]

26. Beck, W. Metal complexes of biologically important ligands, CLXXII [1]. metal ions and metal complexes as protective groups of amino acids and peptides-reactions at coordinated amino acids. Z. Naturforsch. B 2009, 64, 1221-1245. [CrossRef]

27. Zheng, X.D.; Lu, T.B. Constructions of helical coordination compounds. CrystEngComm 2010, 12, $324-336$. [CrossRef]

28. Lamberts, K.; Englert, U. Structures from $\mathrm{MnX}_{2}$ and proline: Isomorphous racemic compounds and a series of chiral non-isomorphous chain polymers. Acta Crystallogr. B 2012, 68, 610-618. [CrossRef]

29. Lamberts, K.; Porsche, S.; Hentschel, B.; Kuhlen, T.; Englert, U. An unusual linker and an unexpected node: $\mathrm{CaCl}_{2}$ dumbbells linked by proline to form square lattice networks. CrystEngComm 2014, 16, 3305-3311. [CrossRef]

30. Lamberts, K.; Möller, A.; Englert, U. Enantiopure and racemic alanine as bridging ligands in Ca and Mn chain polymers. Acta Crystallogr. B 2014, 70, 989-998. [CrossRef]

31. Fleck, M.; Petrosyan, A. Salts of Amino Acids: Crystallization, Structure and Properties; Springer International Publishing: Cham, Switzerland, 2014; pp. 1-574.

32. Lamberts, K.; Şerb, M.D.; Englert, U. Unexpected proline coordination in the copper chain polymer $\left[\mathrm{Cu}(\mu-\mathrm{Cl})_{2}\left(\mu-\mathrm{DL}-\text { proline- } \varkappa_{2} \mathrm{O}: \mathrm{O}^{\prime}\right)\right]_{\infty}^{1}$. Acta Crystallogr. C 2015, 71, 271-275. [CrossRef] 
33. Lamberts, K.; Englert, U. Crystal structures of coordination polymers from $\mathrm{CaI}_{2}$ and proline. Acta Crystallogr. E 2015, 71, 675-680. [CrossRef]

34. Lamberts, K.; Englert, U. Incidental Polymorphism, Non-Isomorphic and Isomorphic Substitution in Calcium-Valine Coordination Polymers. Crystals 2015, 5, 261-272. [CrossRef]

35. Lamberts, K.; Tegoni, M.; Jiang, X.; Kou, H.Z.; Englert, U. Silver complexation by metallacryptates. Dalton Trans. 2016, 45, 284-295. [CrossRef] [PubMed]

36. Yoshinari, N.; Konno, T. Chiral Phenomena in Multinuclear and Metallosupramolecular Coordination Systems Derived from Metalloligands with Thiol-Containing Amino Acids. B Chem. Soc. Jpn. 2018, 91, 790-812. [CrossRef]

37. Subhashini, R.; Arjunan, S.; Gunasekaran, B. Synthesis of a metal coordinated amino acid based nonlinear single crystal, Bis(l-threonine)zinc(II) using the solution growth technique and its physicochemical properties. J. Phys. Chem. Solids 2019, 135, 109077. [CrossRef]

38. Kumary, V.A.; Abraham, P.; S, R.; Swamy, B.K.; Nancy, T.M.; Sreevalsan, A. A novel heterogeneous catalyst based on reduced graphene oxide supported copper coordinated amino acid-A platform for morphine sensing. J. Electroanal. Chem. 2019, 850, 113367. [CrossRef]

39. Castinñeiras, A.; Balboa, S.; Carballo, R.; Niclós, J. The Crystal Structures of two Linearly Polymeric Copper(II) Complexes of 2,2'-Bipyridine with threefold Glycolato and Oxalato Bridges. Z. Anorg. Allg. Chem. 2002, 628, 2353-2359. [CrossRef]

40. Castiñeiras, A.; Balboa, S.; Carballo, R.; González-Pérez, J.M.; Niclós-Gutiérrez, J. Structural Evidences for the Oxidation of $\alpha$-Hydroxycarboxilic Acids to Oxalate Assisted by Copper(II) Ions. Z. Anorg. Allg. Chem. 2007, 633, 717-723. [CrossRef]

41. Dybtsev, D.; Samsonenko, D.; Fedin, V. Porous coordination polymers based on carboxylate complexes of $3 d$ metals. Russ. J. Coord. Chem. 2016, 42, 557-573. [CrossRef]

42. Macrae, C.F.; Edgington, P.R.; McCabe, P.; Pidcock, E.; Shields, G.P.; Taylor, R.; Towler, M.; van de Streek, J. Mercury: Visualization and analysis of crystal structures. J. Appl. Cryst. 2006, 39, 453-457. [CrossRef]

43. Ray, M.S.; Ghosh, A.; Das, A.; Drew, M.G.B.; Ribas-Ariño, J.; Novoa, J.; Ribas, J. A new tetrameric CuII cluster with square topology exhibiting ferro- and antiferromagnetic magnetic pathways: Which is which? Chem. Commun. 2004, 9, 1102-1103. [CrossRef]

44. Groom, C.R.; Bruno, I.J.; Lightfoot, M.P.; Ward, S.C. The Cambridge Structural Database. Acta Crystallogr. B 2016, 72, 171-179. [CrossRef] [PubMed]

45. Kathalikkattil, A.C.; Bisht, K.K.; Aliaga-Alcalde, N.; Suresh, E. Synthesis, Magnetic Properties, and Structural Investigation of Mixed-Ligand $\mathrm{Cu}(\mathrm{II})$ Helical Coordination Polymers with an Amino Acid Backbone and N-Donor Propping: 1-D Helical, 2-D Hexagonal Net (hcb), and 3-D ins Topologies. Cryst. Growth Des. 2011, 11, 1631-1641. [CrossRef]

46. Ingleson, M.J.; Barrio, J.P.; Bacsa, J.; Dickinson, C.; Park, H.; Rosseinsky, M.J. Generation of a solid Brønsted acid site in a chiral framework. Chem. Commun. 2008, 1287-1289. [CrossRef] [PubMed]

47. Antolini, L.; Battaglia, L.P.; Bonamartini Corradi, A.; Marcotrigiano, G.; Menabue, L.; Pellacani, G.C.; Saladini, M.; Sola, M. Tridentate facially coordinated L-aspartate ion complexation with the copper(II) ion: Spectroscopic and structural properties of aqua(L-aspartato)(1,10-phenanthroline)copper(II) tetrahydrate. Inorg. Chem. 1986, 25, 2901-2904. [CrossRef]

48. Ma, L.F.; Liang, F.P.; Qin, H.C.; Hu, R.X.; Zhang, M.B.; Yu, K.B. Synthesis and Crystal Structure of Binuclear Complex $\left[\mathrm{Cu}_{2}(\mathrm{~L}-\mathrm{Asp})(\mathrm{phen})_{3}\left(\mathrm{NO}_{3}\right)\right]\left(\mathrm{NO}_{3}\right) \cdot 4 \mathrm{H}_{2} \mathrm{O}$. Chin. J. Inorg. Chem. 2004, 20, 1429-1432.

49. Baggio, R.F.; Calvo, R.; Brondino, C.; Garland, M.T.; Atria, A.M.; Spodine, E. A Novel Structure of (L-Aspartato)(1,10-phenanthroline)copper(II) Hydrate. Acta Crystallogr. C 1995, 51, 382-385. [CrossRef]

50. Spek, A.L. Structure validation in chemical crystallography. Acta Crystallogr. D 2009, 65, 148-155. [CrossRef]

51. Hörner, T.G.; Klüfers, P. The Species of Fehling's Solution. Eur. J. Inorg. Chem. 2016, 2016, $1798-1807$. [CrossRef]

52. Lueken, H. Magnetochemie; B.G. Teubner: Stuttgart, Germany; Leipzig, Germany, 1999.

53. Calvo, R.; Steren, C.A.; Piro, O.E.; Rojo, T.; Zuniga, F.J.; Castellano, E.E. Crystal structure and magnetic properties of diaqua(L-aspartato)copper(II). Inorg. Chem. 1993, 32, 6016-6022. [CrossRef]

54. Tulsky, E.G.; Long, J.R. Dimensional reduction: A practical formalism for manipulating solid structures. Chem. Mater. 2001, 13, 1149-1166. [CrossRef] 


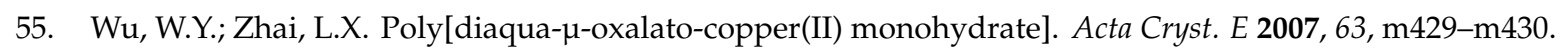
[CrossRef]

56. Yeşilel, O.; Erer, H.; Odabasoglu, M.; Büyükgüngör, O. A Novel Copper(II)-Hydrogen Oxalate Coordination Polymer Showing a New Coordination Mode. J. Inorg. Organomet. Polym. Mater. 2010, 20, 78-82. [CrossRef]

57. Zhang, B. CCDC 1559673. In Experimental Crystal Structure Determination; The Cambridge Crystallographic Data Centre (CCDC): Cambridge, UK, 2017, Volume 20.

58. Ghoshal, D.; Ghosh, A.K.; Mostafa, G.; Ribas, J.; Chaudhuri, N.R. Succinato-bridged copper(II) supramolecular 3D framework: Synthesis, crystal structure and magnetic property. Inorg. Chim. Acta 2007, 360, 1771-1775. [CrossRef]

59. O'Connor, B.H.; Maslen, E.N. The crystal structure of $\mathrm{Cu}(\mathrm{II})$ succinate dihydrate. Acta Crystallogr. 1966, 20, 824-835. [CrossRef]

60. Rastsvetaeva, R.K.; Pushcharovsky, D.Y.; Furmanova, N.G.; Sharp, H. Crystal and molecular structure of $\mathrm{Cu}(\mathrm{II})$ succinate monohydrate or "Never wash copper minerals with detergents". Z. Kristallogr. Cryst. Mater. 1996, 211, 808-811. [CrossRef]

61. Zheng, Y.Q.; Lin, J.L. New 1D and 2D metal oxygen connectivities in $\mathrm{Cu}(\mathrm{II})$ succinato and glutarato coordination polymers: $\left[\mathrm{Cu}_{3}\left(\mathrm{H}_{2} \mathrm{O}\right)_{2}(\mathrm{OH})_{2}\left(\mathrm{C}_{4} \mathrm{H}_{4} \mathrm{O}_{4}\right)_{2}\right] \cdot{ }_{4} \mathrm{H}_{2} \mathrm{O},\left[\mathrm{Cu}_{4}\left(\mathrm{H}_{2} \mathrm{O}\right)_{2}(\mathrm{OH})_{4}\left(\mathrm{C}_{4} \mathrm{H}_{4} \mathrm{O}_{4}\right)_{2}\right] \cdot 5 \mathrm{H}_{2} \mathrm{O}$ and $\left[\mathrm{Cu}_{5}(\mathrm{OH})_{6}\left(\mathrm{C}_{5} \mathrm{H}_{6} \mathrm{O}_{4}\right)_{2}\right] \cdot 4 \mathrm{H}_{2} \mathrm{O}$. J. Coord. Chem. 2008, 61, 3420-3437. [CrossRef]

62. Prout, C.K.; Carruthers, J.R.; Rossotti, F.J.C. Structure and stability of carboxylate complexes. Part VII. Crystal and molecular structures of copper(II)meso-tartrate trihydrate and copper(II)d-tartrate trihydrate. J. Chem. Soc. A 1971, 3336-3342. [CrossRef]

63. Bruker. SAINT+; Bruker AXS Inc.: Madison, WI, USA, 2009.

64. Bruker. SADABS; Bruker AXS Inc.: Madison, WI, USA, 2001.

65. Kabsch, W. XDS. Acta Crystallogr. D 2010, 66, 125-132. [CrossRef]

66. Kabsch, W. Integration, scaling, space-group assignment and post-refinement. Acta Crystallogr. D 2010, 66, 133-144. [CrossRef]

67. Sheldrick, G.M. SHELXT-Integrated space-group and crystal-structure determination. Acta Crystallogr. A 2015, 71, 3-8. [CrossRef]

68. Sheldrick, G.M. A short history of SHELX. Acta Crystallogr. A 2008, 64, 112-122. [CrossRef] [PubMed] 